\section{Modifying a Soilless Root Medium with Aluminum Influences Phosphorus Retention and Chrysanthemum Growth}

\author{
Kimberly A. Williams ${ }^{1}$ and Paul V. Nelson ${ }^{2}$ \\ Department of Horticultural Science, North Carolina State University, Raleigh, \\ NC 27695-7609

\begin{abstract}
Additional index words. Chrysanthemum $\times$ morifolium, Dendranthema $\times$ grandiflorum, soilless substrate, isotherm, fixation, leaching, nutrition
\end{abstract}

\begin{abstract}
Soilless container root media have little capacity to retain $\mathbf{P}$, and preplant amendments of triple superphosphate (TSP) and water-soluble fertilizer (WSF) P applications are readily leached from them. A soilless medium modified with $\mathrm{Al}_{2}\left(\mathrm{SO}_{4}\right)_{3}$ was tested to reduce such $P$ losses. Aluminum sulfate solutions were applied to a 70 sphagnum peat : 30 perlite (v/v) medium to result in $0.32,0.96$, and $1.92 \mathrm{~kg} \mathrm{Al} / \mathrm{m}^{3}$ and dried at $70 \mathrm{C}$. Adsorption isotherms ( $25 \mathrm{C}, 0$ to $500 \mathrm{mg} P /$ liter) showed that $P$ retention increased as the rate of Al addition increased. In a greenhouse study, plants of Dendranthema $\times$ grandiflorum (Ramat.) Kitamura 'Sunny Mandalay' were grown in Al-modified media and an unmodified medium in factorial combination with $P$ from preplant amendment of $0.1 \mathrm{~kg}$ TSP-P/ $\mathrm{m}^{3}$, or $\mathrm{P}$ applied at each watering as WSF at rates of 5.5 or $21.8 \mathrm{mg} P /$ liter. The two highest rates of $\mathrm{Al}$ were excessive and resulted in low $\mathrm{pH}$ and excessive soluble Al levels in the root medium solution early in the cropping cycle, which were detrimental to plant growth. When the root medium was modified with $0.32 \mathrm{~kg} \mathrm{Al} / \mathrm{m}^{3}$, soluble $\mathrm{Al}$ levels in medium solution were not significantly different than in the unmodified control. TSP-P that leached was substantially reduced by the addition of $\mathrm{Al}$, yet sufficient $\mathrm{P}$ was released throughout the cropping cycle for adequate plant growth. Plants grown in Al-modified medium with $0.1 \mathrm{~kg}$ TSP-P $/ \mathrm{m}^{3}$ did not differ from control plants in unmodified medium $+0.27 \mathrm{~kg}$ TSP-P $/ \mathrm{m}^{3}$ and were larger than plants grown in unmodified medium $+0.1 \mathrm{~kg}$ TSP-P $/ \mathrm{m}^{3}$. Aluminum modification of the root medium substantially reduced $P$ leaching when used with WSF containing $P$. In addition, growth of plants in unmodified medium fertilized with $5.5 \mathrm{vs.} 21.8 \mathrm{mg}$ P/liter was similar.
\end{abstract}

Unlike their soil-based predecessors, soilless container root media have virtually no capacity to retain $\mathrm{P}$ (Marconi and Nelson, 1984). In soils, $\mathrm{P}$ is fixed by $\mathrm{Al}$ and $\mathrm{Fe}$ complexes (Sample et al., 1980), but soilless root medium components, such as sphagnum peat and pine bark, lack these binding sites. For greenhouse crop production, high rates of preplant superphosphate coupled with watersoluble fertilizer (WSF) $\mathrm{P}$ applications are usually applied (Nelson, 1991) to compensate

Received for publication 13 July 1995 . Accepted for publication 17 Dec. 1995. This research was funded in part by the North Carolina Agricultural Research Service (NCARS) and by a grant from Sun Gro Horticulture. Use of trade names in this publication does not imply endorsement by NCARS of products named nor criticism of similar ones not mentioned. Appreciation is extended to Yoder Brothers for providing chrysanthemum cuttings. We thank William $\mathrm{H}$. Swallow for his expert statistical guidance. From a thesis submitted by K.A.W. in partial fulfillment of the requirements for the $\mathrm{PhD}$ degree. This paper was presented in part at the ASHS 92nd Annual Meeting, Montreal, Que., 30 July-2 Aug. 1995. The cost of publishing this paper was defrayed in part by the payment of page charges. Under postal regulations, this paper therefore must be hereby marked advertisement solely to indicate this fact. ${ }^{1}$ Graduate Assistant. Current address: Dept. of Natural Resources and Environmental Sciences, 1029 Plant Sciences Laboratory, 1201 S. Dorner Dr., Univ. of Illinois, Urbana, IL 61801.

${ }^{2}$ Professor. for the inability of soilless media to continually renew the medium solution with P. However, these fertilizers are readily leached from the root medium. Modification with $\mathrm{Al}$ or $\mathrm{Fe}$ could retain $\mathrm{P}$, allow a reduction in $\mathrm{P}$ application levels, and reduce $\mathrm{P}$ losses in the leachate. Yeager and Barrett (1986), in a laboratory study with a pine bark-based soilless medium, found that $\mathrm{P}$ leached over 3 weeks decreased with increasing rate of an aluminum acetate amendment. Problems that could be anticipated with using Al-modified root medium during greenhouse crop production include $\mathrm{Al}$ toxicity and $\mathrm{pH}$-lowering effects. The objectives of this study were to determine the effectiveness of $\mathrm{Al}_{2}\left(\mathrm{SO}_{4}\right)_{3}$ modification of a peatbased soilless root medium in increasing $\mathrm{P}$ retention and to assess the side effects of such modification on medium $\mathrm{pH}$ and chrysanthemum growth.

\section{Materials and Methods}

Aluminum-modified medium preparation. Solutions of $\mathrm{Al}_{2}\left(\mathrm{SO}_{4}\right)_{3}$ were added to a medium of 70 sphagnum peat : 30 coarse perlite (v/v) (Krum, Silbrico Co., Hodgkins, Ill.) to the point of saturation $\left(32 \mathrm{ml} / 100 \mathrm{~cm}^{3}\right)$ and then dried at $70 \mathrm{C}$ for $72 \mathrm{~h}$. Solutions were added to provide $\mathrm{Al}$ at $0.32,0.96$, and 1.92 $\mathrm{kg} \cdot \mathrm{m}^{-3}$ medium.

Laboratory experiment. Data for plotting $\mathrm{P}$ adsorption isotherms were obtained by modi- fying the procedures described by Fox and Kamprath (1970). To create adsorption isotherms, $5-\mathrm{cm}^{3}$ samples of each medium were placed into 50-ml centrifuge tubes (sample weight was the same for all replications of each treatment material). Thirty milliliters of $0.01 \mathrm{M} \mathrm{CaCl}_{2}$ that contained $0,100,300$, or 500 $\mathrm{mg} \mathrm{P} /$ liter from $\mathrm{Ca}\left(\mathrm{H}_{2} \mathrm{PO}_{4}\right)_{2}$ was added to each tube, plus two drops of toluene to limit microbial growth. The tubes were capped and placed longitudinally on a circular motion shaker (100 rpm) at $26 \mathrm{C}$ for 10 days. After the equilibration period, the tubes were centrifuged at $5856 \times g$, the supernatant was removed, and supernatant $\mathrm{PO}_{4}-\mathrm{P}$ and $\mathrm{pH}$ were determined. Phosphorus that disappeared from solution was considered to be sorbed by the Al-peat complex or precipitated.

Greenhouse experiment. Treatments were arranged in a randomized complete-block design with three blocks and two pots per experimental unit. The treatment structure was a factorial with three $\mathrm{P}$ fertilizers $\times$ four $\mathrm{Al}$ modification rates. The $\mathrm{P}$ fertilizers were 0.1 $\mathrm{kg} \mathrm{P} / \mathrm{m}^{3}$ medium from preplant amendment with triple superphosphate (TSP); $5.5 \mathrm{mg} \mathrm{P} /$ liter from $0.35 \mathrm{~mm} \mathrm{NH}_{4} \mathrm{H}_{2} \mathrm{PO}_{4}$; and $21.8 \mathrm{mg} \mathrm{P} /$ liter from $1.5 \mathrm{~mm} \mathrm{NH}_{4} \mathrm{H}_{2} \mathrm{PO}_{4}$. All treatments received $4.5 \mathrm{~mm} \mathrm{KNO}_{3}$ and 5.25, 5.15, or 4.5 $\mathrm{mm} \mathrm{NH} \mathrm{NO}_{3}$, respectively. The Al-modification rates were 0 (unmodified), $0.32,0.96$, and, to ensure symptoms of Al toxicity, $1.92 \mathrm{~kg} \mathrm{Al} / \mathrm{m}^{3}$ medium. Two additional controls with plants grown in unmodified medium were 1) $0.27 \mathrm{~kg}$ $\mathrm{P} / \mathrm{m}^{3}$ from preplant amendment with TSP [a standard rate to meet the 12 -week requirement of a chrysanthemum crop (Nelson, 1991)]; and 2) no P. Both of these controls received 4.5 $\mathrm{mm} \mathrm{KNO}_{3}$ and $5.25 \mathrm{~mm} \mathrm{NH}_{4} \mathrm{NO}_{3}$ WSF.

One rooted cutting of 'Sunny Mandalay' pot chrysanthemum (Yoder Brothers, Barberton, Ohio) was planted on 19 Feb. 1994 per 10-cm (diameter) round, green, plastic pot. The medium volume was $500 \mathrm{~cm}^{3}$ and the depth was $10 \mathrm{~cm}$. Root medium was amended with the following materials and rates per cubic meter: $6 \mathrm{~kg}$ dolomitic limestone [49\% Ca carbonate and $36 \% \mathrm{Mg}$ carbonate (v/v)]; $0.9 \mathrm{~kg}$ gypsum; and $3 \mathrm{~kg}$ Esmigran micronutrient mix (Scotts-Sierra Horticultural Products, Marysville, Ohio). All mixes containing Al were additionally amended with $1.8 \mathrm{~kg}$ hydrated lime $/ \mathrm{m}^{3}$ to at least partially adjust for the $\mathrm{pH}$-lowering effects of the Al. TSP prills were ground before incorporation into the media. Pots were spaced $20 \times 28 \mathrm{~cm}$ apart, center to center. Plants received 2 weeks of long days (lighted with incandescent lamps from 2200 to $0200 \mathrm{HR}$ ) followed by 9 weeks of natural short days and were pinched to leave nine nodes 2 weeks after planting. Lateral flower buds were removed 5 weeks after pinching.

The water source had a $\mathrm{pH}=7.0,10 \mathrm{mg} \mathrm{Ca} /$ liter, $3 \mathrm{mg} \mathrm{Mg} / \mathrm{liter}$, and $\mathrm{Ca}$-carbonate equivalent alkalinity of $25 \mathrm{mg} \cdot \mathrm{liter}^{-1}$. Plants were watered at the point that a few individual plants began to express visible stress symptoms. Fertilizer was applied at each watering, except on weekends when plants received tap water. On day 5 of the cropping cycle, all pots 


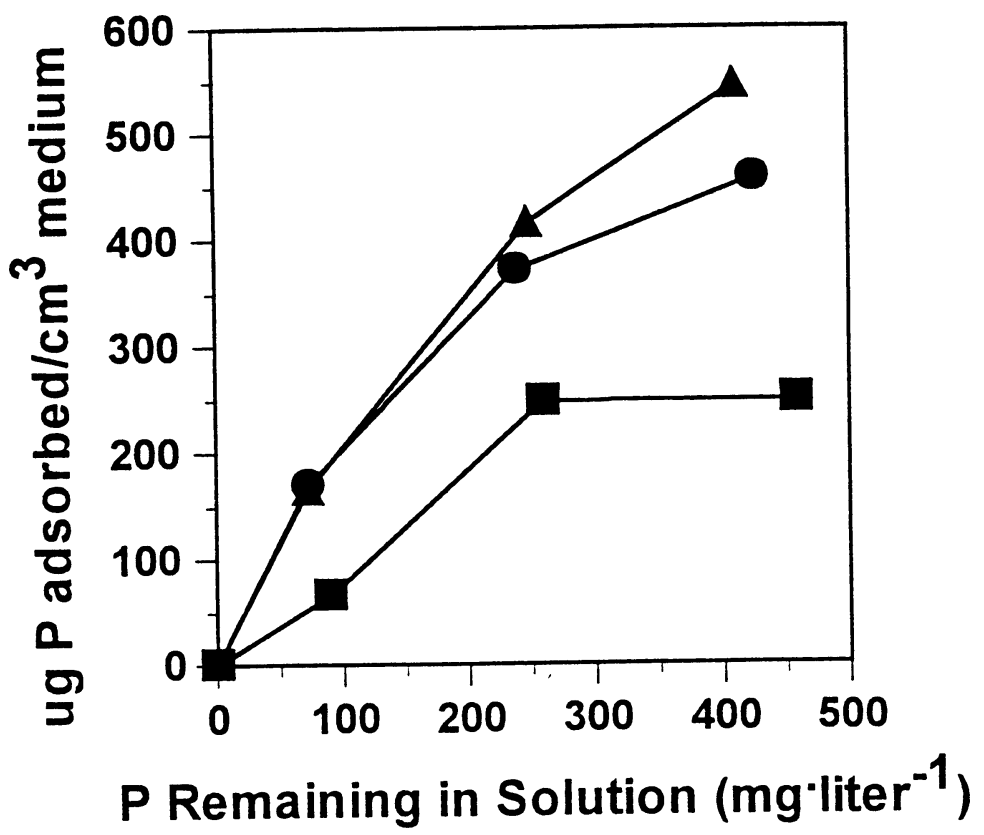

Fig. 1. Phosphorus adsorption isotherms for $(\mathbf{\square}) 70$ sphagnum peat : 30 perlite root medium, () medium $+0.32 \mathrm{~kg} \mathrm{Al} / \mathrm{m}^{3}$, and $(\boldsymbol{\Delta})$ medium $+0.96 \mathrm{~kg} \mathrm{Al} / \mathrm{m}^{3}$.

that normally received WSF at 5.5 or $21.8 \mathrm{mg}$ $\mathrm{P} /$ liter were fertilized once with $65.5 \mathrm{mg} \mathrm{P} /$ liter. The purpose of this application was to attempt saturation of the Al-P binding sites so that the $\mathrm{P}$ regularly applied as WSF at low levels (5.5 and $21.8 \mathrm{mg}$ P/liter) would not be entirely removed from solution and unavailable for plant uptake early in the cropping cycle. The leaching fraction (LF), defined as the volume of leachate divided by the volume of solution applied, was estimated at 0.25. Thermostats were set to turn on heating at $17 \mathrm{C}$ and cooling at $25 \mathrm{C}$. All data were subjected to analysis of variance (PROC ANOVA, SAS Inst., Cary, N.C.) and appropriate LSDS were calculated to compare means within rows or within columns of the factorial treatment structure.

Unaltered medium solution was sampled by vacuum removal on day 2 (2 days after planting), 4, 8, 15, 22, 37, 51, 65, and 75 of the cropping cycle. To accomplish this, tap water was applied to pots, allowed to equilibrate for $1 \mathrm{~h}$, then pots were sealed in a suction funnel and a vacuum was drawn on the base of the pot. Ten milliliters of solution was collected from each of the two pots within an experimental unit and combined. Solution samples were analyzed for $\mathrm{PO}_{4}-\mathrm{P}$ [Chapman and Pratt (1961) for concentrations $>10 \mathrm{mg} \cdot$ liter $^{-1}$ or Murphy and Riley (1962) for concentrations <10 $\mathrm{mg} \cdot$ liter $^{-1}$ ] using a UV/VIS spectrophotometer (Perkin-Elmer, Norwalk, Conn.), and pH was measured using a combined $\mathrm{pH}$ and temperature meter (Extech Instruments Corp., Waltham, Mass.). Soluble Al also was determined for all plants fertilized with $0.1 \mathrm{~kg}$ TSP$\mathrm{P} / \mathrm{m}^{3}$ using an inductively coupled argon plasma emission spectrophotometer (Fisons Instruments, Dearborn, Mich.).

Plant height, width, and quality ratings were recorded weekly. Height was measured from the rim of the pot to the top of the foliage or flower canopy and plant width was taken at the widest diameter. Plant quality ratings were assigned subjectively after consideration of plant volume, form, foliage color, and number and size of flowers using a scale of 1 to 10 , with 10 representing quality surpassing commercial standards for miniature-grade chrysanthemum (Hamrick, 1989). Fresh weight and dry weight (dried for a minimum of $48 \mathrm{~h}$ at $70 \mathrm{C}$ ) of the total above-ground plant shoots were recorded at the end of the crop.

Tissue samples consisted of the youngest, fully expanded leaves at midcrop (day 44) and total above-ground shoots at the end of the crop (day 76). Plant tissue was washed in 0.2 $\mathrm{N} \mathrm{HCl}$ and rinsed in distilled water. Dried tissue was ground in a stainless steel Wiley mill to a particle size $\leq 1 \mathrm{~mm}$ (20-mesh screen). Tissue used for $\mathrm{P}, \mathrm{K}, \mathrm{Ca}, \mathrm{Mg}, \mathrm{S}, \mathrm{Fe}, \mathrm{Mn}, \mathrm{Zn}$, and $\mathrm{Cu}$ analyses was dry-ashed at 500C, dehydrated in $\mathrm{HCl}$, and dissolved in $0.5 \mathrm{~N} \mathrm{HCl}$. Total $\mathrm{N}$ was determined using a micro-Kjeldahl procedure after pretreatment with salicylic acid to aid in the reduction of nitrate (Eastin, 1978). Analysis of K, Ca, Mg, Fe, Mn, Zn, and $\mathrm{Cu}$ was conducted using atomic absorption spectroscopy. Phosphorus was measured using the same colorimetric methods used to analyze the root medium solution.

\section{Results and Discussion}

Laboratory experiment. The adsorption isotherms indicated that $\mathrm{Al}$ modification increased the capacity of the 70 peat : 30 perlite medium to retain $\mathrm{P}$ (Fig. 1). The slope of the plot of $\mathrm{P}$ adsorbed vs. P remaining in solution is an indication of the P buffering capacity of the medium (Ozanne and Shaw, 1968); the greater the slope, the greater the ability of the root medium to renew the medium solution with P. Phosphorus buffering capacity was highest at the highest rate of Al modification.
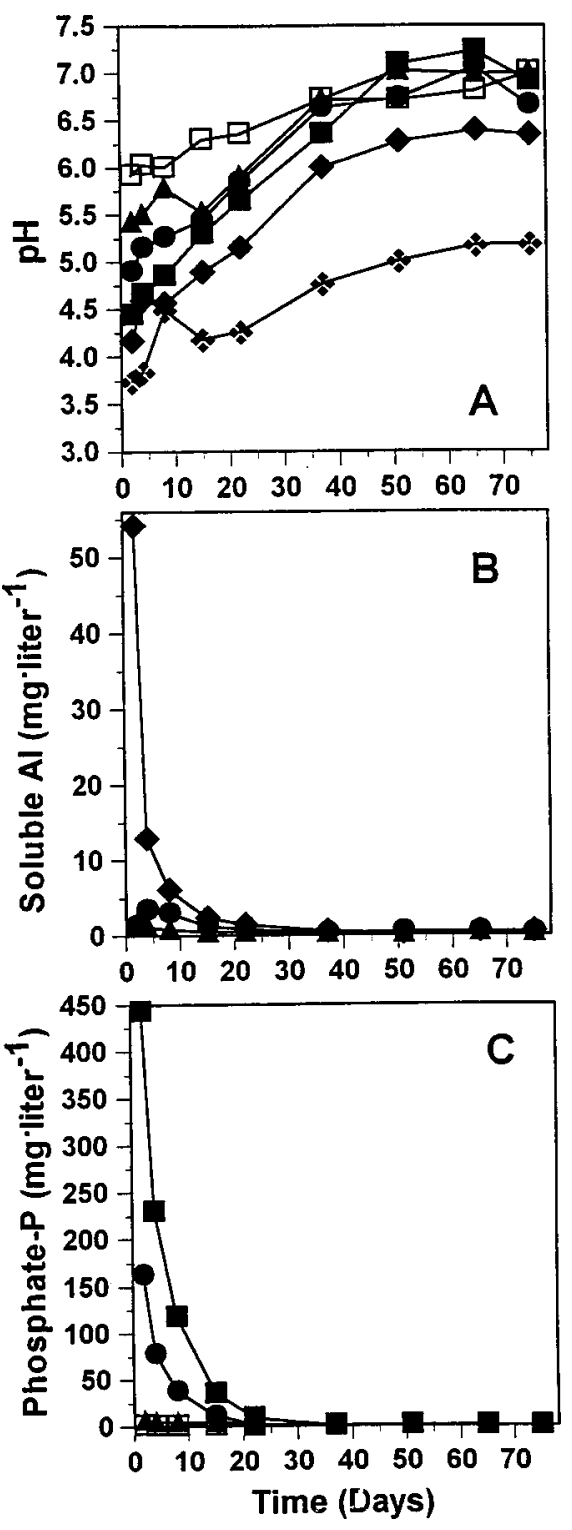

Fig. 2. pH, soluble $\mathrm{Al}$, and $\mathrm{PO}_{4}-\mathrm{P}$ concentrations of root medium solution from greenhouse-grown chrysanthemums for treatments containing TSP$\mathrm{P}: \mathbf{Q}=$ unmodified medium $+0.1 \mathrm{~kg} \mathrm{P} / \mathrm{m}^{3} ; \mathbf{\square}=$ unmodified medium $+0.27 \mathrm{~kg} \mathrm{P} / \mathrm{m}^{3} ; \square=-\mathrm{P}$ control; $\boldsymbol{\Delta}=0.32 \mathrm{~kg} \mathrm{Al} / \mathrm{m}^{3}+0.1 \mathrm{~kg} \mathrm{P} / \mathrm{m}^{3} ; \bullet=$ $0.96 \mathrm{~kg} \mathrm{Al} / \mathrm{m}^{3}+0.1 \mathrm{~kg} \mathrm{P} / \mathrm{m}^{3} ;=1.92 \mathrm{~kg} \mathrm{Al} / \mathrm{m}^{3}$ $+0.1 \mathrm{~kg} \mathrm{P} / \mathrm{m}^{3}$. (A) $\mathrm{pH}(\mathrm{sE}=$ mean \pm 0.1$) ;(\mathbf{B})$ soluble $\mathrm{Al}(\mathrm{sE}=$ mean \pm 9.2$)$; and $(\mathbf{C}) \mathrm{PO}_{4}-\mathrm{P}(\mathrm{sE}$ $=$ mean \pm 3.8 ).

Greenhouse experiment. The highest rate of $\mathrm{Al}$ modification, $1.92 \mathrm{~kg} \mathrm{Al} / \mathrm{m}^{3}$ medium, resulted in soluble $\mathrm{Al}$ levels of $649,291,84$, and $0.8 \mathrm{mg} \mathrm{Al} /$ liter in the root medium solution on day $2,4,8$, and 75 of the cropping cycle, respectively. The excessive Al levels resulted in lowered root medium $\mathrm{pH}$ (Fig. 2A), severely stunted growth, necrosis of the lower foliage, and limited root systems with brown root tips. The next lower initial rate of $\mathrm{Al}$ modification, $0.96 \mathrm{~kg} \cdot \mathrm{m}^{-3}$, also resulted in excessive soluble $\mathrm{Al}$ in the root medium solution early in the cropping cycle (Fig. 2B), low $\mathrm{pH}$ in the medium solution early in the cropping cycle (Figs. 2A and 3B), and reduced growth (Table 1). Tissue concentrations of all 
essential mineral nutrients tested, other than $\mathrm{P}$ met accepted minimum standard levels (Jones et al., 1991) with inconsequential exceptions at mid- and end of crop (data not shown). Because of the reduced quality of plants grown at 0.96 and $1.92 \mathrm{~kg} \mathrm{Al} / \mathrm{m}^{3}$, use of these rates is not recommended, despite the potential benefit of reduced $\mathrm{P}$ in the leachate (Fig. 3A; data not shown for $1.92 \mathrm{~kg} \mathrm{Al} / \mathrm{m}^{3}$ rate).

However, when the root medium was modified with $\mathrm{Al}$ at the lowest rate, $0.32 \mathrm{~kg} \cdot \mathrm{m}^{-3}$, neither $\mathrm{pH}$ nor soluble Al levels in the medium solution were significantly different than in the unmodified controls (Figs. $2 \mathrm{~A}$ and B and $3 \mathrm{~B})$, except on a few dates early in the cropping cycle when slightly higher $\mathrm{pH}$ levels were measured in pots modified with $\mathrm{Al}$ at 0.32 $\mathrm{kg} \cdot \mathrm{m}^{-3}$ compared to unmodified controls. This result likely is explained by the additional preplant amendment of hydrated lime to the Al-modified medium. Plant growth was not impaired by modification with $\mathrm{Al}$ at this lowest rate (Table 1).

Modification of root medium with $\mathrm{Al}$ at $0.32 \mathrm{~kg} \cdot \mathrm{m}^{-3}$ substantially reduced $\mathrm{P}$ losses in root medium solution (Fig. 2C). Phosphorus levels measured in the medium solution were $6.3,4.9,4.1,0.2,0.2$, and $0.1 \mathrm{mg} \mathrm{P} / \mathrm{liter}$ on days
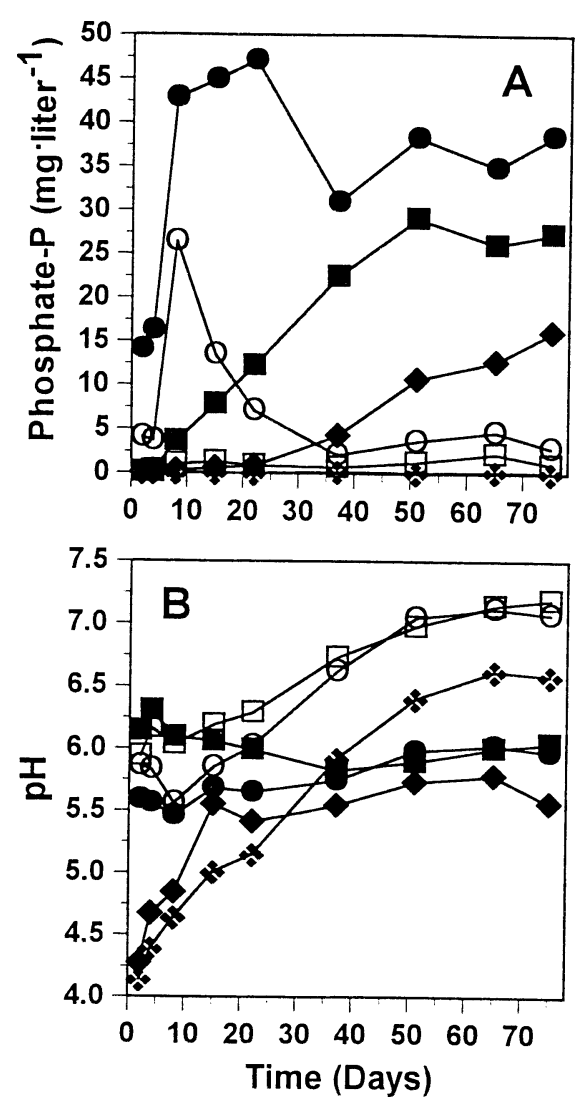

Fig. 3. Phosphate-P and $\mathrm{pH}$ concentrations of the root medium solution from greenhouse-grown chrysanthemums for treatments receiving WSF$\mathrm{P}: \mathrm{O}=$ unmodified medium $+5.5 \mathrm{mg} \mathrm{P} / \mathrm{liter}$ WSF; $=$ unmodified medium $+21.8 \mathrm{mg}$ P/liter WSF; $\square=0.32 \mathrm{~kg} \mathrm{Al} / \mathrm{m}^{3}+5.5 \mathrm{mg}$ P/liter WSF; $\boldsymbol{\square}=0.32 \mathrm{~kg} \mathrm{Al} / \mathrm{m}^{3}+21.8 \mathrm{mg}$ P/liter WSF; $0.96 \mathrm{~kg} \mathrm{Al} / \mathrm{m}^{3}+5.5 \mathrm{mg} \mathrm{P} / \mathrm{liter} \mathrm{WSF} ;=0.96 \mathrm{~kg}$ $\mathrm{Al} / \mathrm{m}^{3}+21.8 \mathrm{mg} \mathrm{P} / \mathrm{liter}$ WSF. (A) $\mathrm{PO}_{4}-\mathrm{P}(\mathrm{sE}=$ mean \pm 3.8$) ;(\mathbf{B}) \mathrm{pH}(\mathrm{SE}=$ mean \pm 0.1$)$
$2,4,15,51,65$, and 75 , respectively, for pots with $0.32 \mathrm{~kg} \mathrm{Al} / \mathrm{m}^{3}+0.1 \mathrm{~kg}$ TSP-P $/ \mathrm{m}^{3}$ compared to $162,77.9,11.4,0.3,0.1$, and 0.1 , respectively, for the unmodified control +0.1 $\mathrm{kg}$ TSP-P $/ \mathrm{m}^{3}$. The pattern of these results was similar to that obtained by Yeager and Barrett (1986) in a laboratory experiment with $\mathrm{Al}$

Table 1. Plant growth characteristics for whole above-

acetate-amended, pine-bark-based medium. By increasing the capacity of the medium to retain $\mathrm{P}$, the $\mathrm{Al}$ amendment resulted in a lower initial $\mathrm{P}$ level and a similar final level, thus shifting $\mathrm{P}$ availability more in accordance with plant requirements. Nishimoto et al. (1975) established that $0.2 \mathrm{mg} \mathrm{P} /$ liter in the root medium

-ground chrysanthemum shoots at end of crop (day 76 ) from plants grown in media modified with $\mathrm{Al}_{2}\left(\mathrm{SO}_{4}\right)_{3}$ and controls. ${ }^{\mathrm{z}}$ Phosphorus was supplied by triple superphosphate (TSP) or water-soluble fertilizer (WSF).

\begin{tabular}{|c|c|c|c|c|c|}
\hline \multirow[b]{2}{*}{ Al modification/P fertilizer } & \multirow{2}{*}{$\begin{array}{c}\mathrm{Ht} \\
(\mathrm{cm})\end{array}$} & \multirow{2}{*}{$\begin{array}{c}\text { Width } \\
(\mathrm{cm})\end{array}$} & \multicolumn{2}{|c|}{$\mathrm{Wt}(\mathrm{g})$} & \multirow[b]{2}{*}{ Rating $^{\mathrm{y}}$} \\
\hline & & & Fresh & Dry & \\
\hline \multicolumn{6}{|c|}{ Additional controls } \\
\hline $0.27 \mathrm{~kg} \mathrm{P} / \mathrm{m}^{3} ; \mathrm{TSP}$ & 21.6 & 29.8 & 109 & 16.7 & 8.0 \\
\hline 0 mg P/liter; WSF & 8.4 & 10.1 & 6.3 & 1.6 & 2.0 \\
\hline \multicolumn{6}{|c|}{ Unmodified } \\
\hline $0.1 \mathrm{~kg} \mathrm{P} / \mathrm{m}^{3} ; \mathrm{TSP}$ & 19.7 & 26.0 & 69.7 & 13.0 & 7.0 \\
\hline $5.5 \mathrm{mg}$ P/liter; WSF & 21.6 & 31.0 & 142 & 16.9 & 9.0 \\
\hline 21.8 mg P/liter; WSF & 22.8 & 32.9 & 148 & 17.0 & 9.3 \\
\hline \multicolumn{6}{|c|}{ Modified with $0.32 \mathrm{~kg} \mathrm{Al} / \mathrm{m}^{3}$ from $\mathrm{Al}_{2}\left(\mathrm{SO}_{4}\right)_{3}$} \\
\hline $0.1 \mathrm{~kg} \mathrm{P} / \mathrm{m}^{3} ; \mathrm{TSP}$ & 21.4 & 30.3 & 118 & 15.8 & 9.0 \\
\hline $5.5 \mathrm{mg}$ P/liter; WSF & 20.7 & 30.4 & 115 & 13.7 & 8.3 \\
\hline $21.8 \mathrm{mg}$ P/liter; WSF & 20.4 & 32.7 & 121 & 14.2 & 8.7 \\
\hline \multicolumn{6}{|c|}{ Modified with $0.96 \mathrm{~kg} \mathrm{Al} / \mathrm{m}^{3}$ from $\mathrm{Al}_{2}\left(\mathrm{SO}_{4}\right)_{3}$} \\
\hline $0.1 \mathrm{~kg} \mathrm{P} / \mathrm{m}^{3} ; \mathrm{TSP}$ & 16.8 & 23.3 & 66.8 & 8.5 & 6.7 \\
\hline $5.5 \mathrm{mg}$ P/liter; WSF & 19.2 & 28.6 & 93.6 & 10.9 & 6.7 \\
\hline $21.8 \mathrm{mg}$ P/liter; WSF & 19.1 & 29.7 & 109 & 12.4 & 7.3 \\
\hline $\operatorname{LSD} \alpha=0.05^{\mathrm{x}}$ & 2.6 & 4.3 & 21.5 & 2.4 & 1.2 \\
\hline \multirow[t]{2}{*}{$\operatorname{LSD} \alpha=0.05$} & $\mathrm{NS}^{\mathrm{w}}$ & $2.3^{\mathrm{w}}$ & $23.4^{\mathrm{v}}$ & $2.6^{\mathrm{v}}$ & $1.2^{\mathrm{v}}$ \\
\hline & $1.6^{\mathrm{u}}$ & $2.7^{\mathrm{u}}$ & & & \\
\hline
\end{tabular}

${ }^{2}$ Values presented are means of three replications (blocks) with two plants per replication (experimental unit).

yPlant quality ratings were assigned subjectively after consideration of plant volume, form, foliage color, and number and size of flowers using a scale of 1 to 10 , with 10 representing quality surpassing commercial standards for miniature-grade chrysanthemum (Hamrick, 1989).

${ }^{\mathrm{x}}$ LSD used only to compare controls with treatments.

${ }^{\mathrm{w}}$ LSD used for comparing Al-modification level at a given fertilizer level; fertilizer $\times$ Al-modification interaction is nonsignificant (NS).

${ }^{\vee}$ LSD used for comparing fertilizer level at a given Al-modification level and Al-modification level at a given fertilizer level; significant fertilizer $\times$ Al-modification interaction.

"LSD used for comparing fertilizer level at a given Al-modification level; fertilizer $\times$ Al-modification interaction is nonsignificant.

Table 2. Phophorus content (dry-weight basis) of the youngest fully expanded leaves collected at midcrop (day 44) and of whole above-ground plant tissue at end of crop (day 76) from chrysanthemum plants grown in media modified with $\mathrm{Al}_{2}\left(\mathrm{SO}_{4}\right)_{3}$ and controls. ${ }^{\mathrm{z}}$ Phosphorus was supplied by triple superphosphate (TSP) or water-soluble fertilizer (WSF).

\begin{tabular}{|c|c|c|c|}
\hline \multirow[b]{2}{*}{ Al modification/P fertilizer } & \multicolumn{2}{|c|}{$\mathrm{P}(\%)$} & \multirow{2}{*}{$\begin{array}{c}\text { Total Py } \\
(\mathrm{mg})\end{array}$} \\
\hline & Midcrop & End of crop & \\
\hline \multicolumn{4}{|c|}{ Additional controls } \\
\hline $0.27 \mathrm{~kg} \mathrm{P} / \mathrm{m}^{3} ; \mathrm{TSP}$ & 0.21 & 0.12 & 19.6 \\
\hline 0 mg P/liter; WSF & 0.009 & 0.37 & 5.6 \\
\hline \multicolumn{4}{|c|}{ Unmodified } \\
\hline $0.1 \mathrm{~kg} \mathrm{P} / \mathrm{m}^{3} ; \mathrm{TSP}$ & 0.16 & 0.08 & 10.3 \\
\hline $5.5 \mathrm{mg}$ P/liter; WSF & 0.37 & 0.26 & 44.8 \\
\hline $21.8 \mathrm{mg}$ P/liter; WSF & 0.77 & 0.74 & 124.7 \\
\hline \multicolumn{4}{|c|}{ Modified with $0.32 \mathrm{~kg} \mathrm{Al} / \mathrm{m}^{3}$ from $\mathrm{Al}_{2}\left(\mathrm{SO}_{4}\right)_{3}$} \\
\hline $0.1 \mathrm{~kg} \mathrm{P} / \mathrm{m}^{3} ; \mathrm{TSP}$ & 0.31 & 0.18 & 28.0 \\
\hline $5.5 \mathrm{mg}$ P/liter; WSF & 0.38 & 0.27 & 36.7 \\
\hline $21.8 \mathrm{mg}$ P/liter; WSF & 0.74 & 0.68 & 96.2 \\
\hline \multicolumn{4}{|c|}{ Modified with $0.96 \mathrm{~kg} \mathrm{Al} / \mathrm{m}^{3}$ from $\mathrm{Al}_{2}\left(\mathrm{SO}_{4}\right)_{3}$} \\
\hline $0.1 \mathrm{~kg} \mathrm{P} / \mathrm{m}^{3} ; \mathrm{TSP}$ & 0.23 & 0.16 & 13.7 \\
\hline 5.5 mg P/liter; WSF & 0.31 & 0.29 & 31.8 \\
\hline $21.8 \mathrm{mg}$ P/liter; WSF & 0.58 & 0.56 & 69.9 \\
\hline $\operatorname{LSD} \alpha=0.05^{\mathrm{x}}$ & 0.06 & 0.25 & 34.5 \\
\hline LSD $\alpha=0.05$ & $0.06^{\mathrm{w}}$ & $0.07^{w}$ & $9.8^{\mathrm{w}}$ \\
\hline
\end{tabular}

${ }^{\mathrm{z}}$ Values presented are means of three replications (blocks) with two plants in each replication (experimental unit).

yTotal $\mathrm{mg} \mathrm{P}$ recovered in the whole above-ground plant tissue.

${ }^{\mathrm{x}}$ LSD used only to compare controls with treatments.

${ }^{{ }}$LSD used for comparing fertilizer level at a given Al-modification level and Al-modification level at a given fertilizer level; significant fertilizer $\times$ Al-modification interaction. 
solution is nonlimiting for optimal growth of chrysanthemum in field soils. On this basis, the low P levels that were available for plant uptake from the Al-peat complex in this experiment should have been adequate for commercially acceptable plant growth until perhaps the last week of the cropping cycle. In fact, the growth characteristics (Table 1) indicated that plants grown with $0.32 \mathrm{~kg} \mathrm{Al} / \mathrm{m}^{3}+$ $0.1 \mathrm{~kg} \mathrm{TSP}-\mathrm{P} / \mathrm{m}^{3}$ were significantly larger than plants grown in unmodified medium $+0.1 \mathrm{~kg}$ $\mathrm{TSP}-\mathrm{P} / \mathrm{m}^{3}$ and not of significantly different size than plants grown in unmodified medium $+0.27 \mathrm{~kg}$ TSP-P $/ \mathrm{m}^{3}$, a commercial standard rate of TSP application. Plants grown in unmodified medium $+0.1 \mathrm{~kg}$ TSP-P $/ \mathrm{m}^{3}$ showed symptoms of $\mathrm{P}$ deficiency, including purpling of the lower and mid leaves of the foliage canopy; plants grown in medium modified with $0.32 \mathrm{~kg} \mathrm{Al} / \mathrm{m}^{3}+0.1 \mathrm{~kg}$ TSP-P $/ \mathrm{m}^{3}$ and those grown in unmodified medium $+0.27 \mathrm{~kg}$ $\mathrm{TSP}-\mathrm{P} / \mathrm{m}^{3}$ had no visual symptoms of $\mathrm{P}$ deficiency. Based on tissue analysis (Table 2), $\mathrm{P}$ concentrations at mid- and end of crop and total $\mathrm{P}$ in shoots at end of crop were not significantly different for plants grown in 0.32 $\mathrm{kg} \mathrm{Al} / \mathrm{m}^{3}+0.1 \mathrm{~kg}$ TSP-P $/ \mathrm{m}^{3}$ vs. those grown in unmodified medium $+0.27 \mathrm{~kg}$ TSP-P $/ \mathrm{m}^{3}$, but were higher than those grown in unmodified medium $+0.1 \mathrm{~kg}$ TSP-P $/ \mathrm{m}^{3}$. However, P tissue concentrations at end of crop of plants grown with TSP-P, including the commercial control of unmodified medium $+0.27 \mathrm{~kg}$ TSP-P $/ \mathrm{m}^{3}$, did not meet the established minimum critical level of $0.23 \% \mathrm{P}$ (Jones et al., 1991). So, while $\mathrm{Al}$ modification at $0.32 \mathrm{~kg} \cdot \mathrm{m}^{-3}$ effectively retained TSP-P in the pot and released it more in accordance with plant requirements over the course of the cropping cycle, an initial rate of TSP higher than $0.1 \mathrm{~kg}$ TSP-P $/ \mathrm{m}^{3}$ with the $\mathrm{Al}$ modification may be needed to provide the longevity of $\mathrm{P}$ release required to meet plant growth demands toward the end of an 11-week cropping cycle.

The use of the $\mathrm{Al}$ modification at 0.32 $\mathrm{kg} \cdot \mathrm{m}^{-3}$ with the WSF applications of 5.5 and $21.8 \mathrm{mg}$ P/liter substantially reduced P levels in the root medium solution compared to the unmodified controls (Fig. 3A); thus, it follows that $\mathrm{P}$ lost through leaching was probably successfully reduced in the presence of the Al. Plants grown in medium with $0.32 \mathrm{~kg} \mathrm{Al} / \mathrm{m}^{3}$ and 5.5 and $21.8 \mathrm{mg}$ P/liter WSF had lower fresh and dry weights than those grown in unmodified medium (Table 1) but were similar in the other three growth characteristics. Tissue $\mathrm{P}$ levels of plants grown in medium modified with $0.32 \mathrm{~kg} \mathrm{Al} / \mathrm{m}^{3}$ and WSF applications of 5.5 and $21.8 \mathrm{mg}$ P/liter were not significantly different than those in plants grown with the same fertilizer but in unmodified medium, and all of these treatments resulted in tissue $\mathrm{P}$ concentrations above accepted minimum critical levels at mid- and end of crop (Jones et al., 1991) (Table 2). The reduction in weights could have been due to the low root medium solution P levels at the beginning of the crop that resulted from the removal of $\mathrm{P}$ from solution by the Al. A small amount of preplant TSP might have alleviated this situation. Aluminum modification provided the benefit of reduced medium solution $\mathrm{P}$ concentrations with WSF-P applications, and plant response in Al-modified medium was similar to that in unmodified medium in the commercially important characteristics of height and width.

An interesting comparison was of plant growth in unmodified medium fertilized with 5.5 or $21.8 \mathrm{mg}$ P/liter WSF: plant growth was not significantly different at these two concentrations of $\mathrm{P}$ application (Table 1). Tissue $\mathrm{P}$ levels were significantly different; however, concentrations in plants grown with $5.5 \mathrm{mg} \mathrm{P/}$ liter WSF surpassed the minimum critical $\mathrm{P}$ levels of $0.23 \%$ to $0.25 \%$ (Jones et al., 1991), and the high $\mathrm{P}$ concentrations and total $\mathrm{P}$ in plants grown with $21.8 \mathrm{mg}$ P/liter WSF were indicative of luxury consumption. We interpret these data as indicating that chrysanthemums can be grown at lower levels of WSF-P application than are commonly applied, which, in turn, would result in lower levels of P lost in the leachate with no other change in production practices. Importantly, the acceptable level of WSF-P depends on the root medium solution $\mathrm{pH}$. Therefore, growers would not be advised to reduce WSF-P levels as low as 5.5 mg P/liter until more data are available.

In summary, this study provided initial data to support alternative strategies that growers might use to reduce $\mathrm{P}$ leaching from a nonrecycling cultural production system while preserving plant quality. The first strategy is the use of root medium modified with $\mathrm{Al}$ at a rate no higher than $0.32 \mathrm{~kg} \cdot \mathrm{m}^{-3}$ to reduce $\mathrm{P}$ losses from TSP- and WSF-P application. Second, the rate of WSF-P application itself could possibly be reduced. Both strategies require refinement and verification before adoption.

\section{Literature Cited}

Chapman, H.D. and P.F. Pratt. 1961. Methods of analysis for soils, plants, and waters. Univ. of California, Div. Agr. Sci., Berkeley.

Eastin, E.F. 1978. Total nitrogen determination for plant material containing nitrate. Anal. Biochem. 85:591-594.

Fox, R.L. and E.J. Kamprath. 1970. Phosphate sorption isotherms for evaluating the phosphate requirements of soils. Soil Sci. Soc. Amer. Proc. 34:902-906.

Hamrick, D.J. (ed.). 1989. PMA recommended grades and standards for pot plants. GrowerTalks 53(4):14-15.

Jones, J.B., B. Wolf, and H.A. Mills. 1991. Plant analysis handbook: A practical sampling, preparation, analysis, and interpretation guide. Micro-Macro Publishing, Athens, Ga.

Marconi, D.J. and P.V. Nelson. 1984. Leaching of applied phosphorus in container media. Scientia Hort. 22:275-285.

Murphy, J. and J.F. Riley. 1962. A modified single solution method for the determination of phosphate in natural waters. Anal. Chim. Acta 27:3136.

Nelson, P.V. 1991. Greenhouse operation and management. 4th ed. Reston Publishing Co., Reston, Va.

Nishimoto, R.K., R.L. Fox, and P.E. Parvin. 1975. External and internal phosphate requirements of field-grown chrysanthemums. HortScience 10:279-280.

Ozanne, P.G. and T.C. Shaw. 1968. Advantages of the recently developed phosphate sorption test over the older extractant methods for soil phosphate. Intl. Congr. Soil Sci., Trans. 9th (Adelaide, Australia) 2:273-280.

Sample, E.C., R.J. Soper, and G.J. Racz. 1980. Reactions of phosphate fertilizers in soils, p. 263-310. In: F.E. Khasawneh, E.C. Sample, and E.J. Kamprath (eds.). The role of phosphorus in agriculture. Amer. Soc. Agron., Crop Sci. Soc. Amer., and Soil Sci. Soc. Amer., Madison, Wis.

Yeager, T.H. and J.E. Barrett. 1986. Influence of an aluminum amendment on phosphorus leaching from a container medium. HortScience 21:262263. 